\title{
ERRATUM
}

\section{Effect of Oxytetracycline-Medicated Feed on Antibiotic Resistance of Gram-Negative Bacteria in Catfish Ponds}

\author{
ANGELO DEPAOLA, JAMES T. PELLER, AND GARY E. RODRICK
}

\author{
Gulf Coast Seafood Laboratory, U.S. Food and Drug Administration, Dauphin Island, Alabama 36528; Center for Food Safety and \\ Applied Nutrition, U.S. Food and Drug Administration, Washington, D.C. 20204; and Department of Food Science
} and Human Nutrition, University of Florida, Gainesville, Florida 32611

Vol. 61, no. 6, p. 2338, Table 5, column 2, last line: "9" should read "97.9." 